\title{
Profile of adolescent users of physical activity programs offered in the Primary Health Care System
}

\author{
Perfil de usuários adolescentes atendidos em programas de atividade \\ física oferecidos na atenção básica à saúde
}

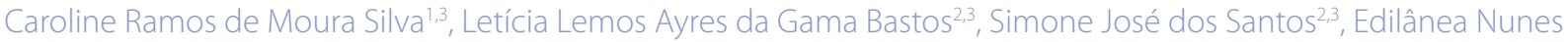
Mélo ${ }^{2,3}$, Agostinho Gonçalves da Silva Júnior ${ }^{2,3}$, Mauro Virgílio Gomes de Barros ${ }^{1,2,3}$

\begin{abstract}
The aim of this study was to describe the profile of adolescent users of interventions of physical activity promotion developed by the primary health care system in the state of Pernambuco. To do so, a state wide cross-sectional study was conducted, derived from the SUS+Ativo project, in which 80 adolescent users were recruited among the users of programs/interventions for physical activity promotion. A total of 112 municipalities were visited in 11 health management regionals in the state of Pernambuco. The data were collected through questionnaires including demographics, health perception and participation in interventions. Overall, 60\% were aged between $15-19$ years, $67.5 \%$ were girls, $83.3 \%$ responded to race as non-white and $68 \%$ resided in urban areas. Positive health perception was referred to by $77.5 \%$, while $97.5 \%$ reported that participating in offered activities contributed to an increase in individual health. Also, $92.5 \%$ informed that the activities offered were the ones they would like to participate in and $37.5 \%$ reported health related factors as the main motive for participation, however, $18.8 \%$ mentioned current health condition as the main barrier for participation. It was observed that $39.2 \%$ of adolescents declared participating in physical activities in two days/week and that for $69.6 \%$ the sessions were 60 minutes or longer. The results of this study indicate that adolescent users of programs/interventions of physical activity promotion are heterogeneous in demographics, health characteristics and participation in the offered services.
\end{abstract} Keywords

Health Promotion; Interventions; Youth; Motor Activity.

\section{Resumo}

O objetivo deste estudo foi descrever o perfil dos usuários adolescentes atendidos em intervenções para promoção da atividade física que são desenvolvidas na atenção básica à saúde no estado de Pernambuco. Para desenvolvimento do mesmo, recorreu-se a um delineamento transversal de abrangência estadual, derivado da realização do projeto SUS+Ativo, no qual participaram 80 usuários adolescentes recrutados entre os usuários de programas/intervenções para promoção da atividade física. Foram visitados 112 municípios em 11 Gerências Regionais de Saúde do estado de Pernambuco. Os dados foram coletados mediante aplicação de um questionário abrangendo aspectos demográficos, da percepção de saúde e da participação nas intervenções. Dos participantes, 60\% tinham idade de 15-19 anos, $67,5 \%$ eram moças, $83,3 \%$ referiram cor da pele não branca e $68 \%$ residiam em áreas urbanas. Percepção de saúde positiva foi referida por $77,5 \%$, enquanto $97,5 \%$ relataram que a participação nas atividades oferecidas contribuiu para a melhoria do nivel de saúde individual. Verificou-se que 92,5\% informaram que as atividades oferecidas eram aquelas nas quais eles realmente gostariam de participar e 37,5\% relataram fatores relacionados à saúde como principal motivo para participação nas atividades, mas, para 18,8\% a condição atual de saúde representou a principal barreira para participação. Observou-se que 39,2\% adolescentes declararam participar de atividades físicas em dois dias/semana e que para 69,6\% as sessões duravam 60 minutos ou mais. Os achados deste estudo indicam que os usuários adolescentes de programas/intervenções para promoção da atividade física são bastante heterogêneos em suas características demográficas, de saúde e de participação nos serviços oferecidos.

\section{Palavras-chave}

Promoção da saúde; Intervenções; Jovem; Atividade motora.

\section{Introduction}

The promotion of physical activity (PA) in Brazil has increased with the publication of the National Policy

1 Graduate Program in Adolescent Health of the University of Pernambuco, Camaragibe-PE, Brazil.

2 Associate Graduate Program in Physical Education UPE/UFPB, Recife-PE, Brazil. 3 Research Group in Lifestyles and Health - GPES. for Health Promotion (NPHP) in 2006, which included the action of "PA practice" in the priority strategy agenda ${ }^{1}$. Thereby, it has been observed the expansion in initiatives looking to provide adhesion to healthy behaviors among the users of the different population subgroups ${ }^{2}$.

The improvement of such initiatives resulted in the 
Academia da Saude Program (PAS), institutionalized in Brazil, in 2011, in order to contribute to the health promotion of the population and serve as one of the entrance doors for the health network ${ }^{3}$. Such initiatives are also present in the state of Pernambuco, highlighting the Academia da Cidade Program (PAC) in Recife, implemented in 2002, aiming to promote physical activity and leisure in the community ${ }^{4}$. In 2007, as a strategy for expansion of the PAC throughout the state of Pernambuco, the government launched the Academia das Cidades Program, a governmental initiative to expand the actions for physical activity promotion in the state.

In the context of articulation and effectuation of public policy, the Ministry of Health created, in 2008, the Nuclei for Support to Family Health (NSFH). The NSFH would be composed by professionals from diverse areas of health, acting integrated to the health network of services looking forward to the expansion and the scope of actions in primary care, including theme axis prioritized in the NPHP, contemplating PA practice ${ }^{5}$.

In spite of the importance of PA for health promotion, it is still a high prevalence of exposure to low physical activity levels of PA in the population ${ }^{6}$. In adolescents, such prevalence is high in many countries ${ }^{7}$, including Brazil ${ }^{8}$. In Pernambuco, it is estimated that $65 \%$ of students in state public schools, aged between 14 and 19 years, present insuficiente levels of $\mathrm{PA}^{9}$. This epidemiological scenario, allied to the recognition that teenage years represent a critical period for stabilization of many conducts of health, demands the development of programs and/ or interventions focused in the elevation of physical activity levels. However, the effectiveness of the interventions depends, beyond other factors, of the capacity to attract and maintain participants in offered activities.

The attraction and maintenance of participants in programs/interventions depend on the recognition of demographic characteristics of potential clientele and of factors that may clarify the participation in offered activities. For example, in a program/intervention that aims to target the needs and interests of adolescents is very important to know if the offered activities are adequate to their age and reach the expectations of potential users. In the context of primary health care, interventions for PA promotion seem to meet the demands of middle aged and older adults ${ }^{10,11}$, while the reasons for low participation of adolescents remain unknown. Therefore, the aim of this study was to describe the profile of adolescent users of interventions for physical activity promotion developed in the primary health care system in the state of Pernambuco.

\section{Methods}

While developing this study on a state wide cross-sectional design, it is part of a project entitled SUS+Ativo (Evaluation of programs and interventions related to physical activity in the primary health care network in the state of Pernambuco). That research project was approved by the Ethics Committee for Research with human beings of the University of Pernambuco (CAAE: 13373313.5.0000.5207).

The state of Pernambuco is composed by 184 municipalities as well as the island of Fernando de Noronha, and it is geographically divided in five regions (metropolitan, zona da mata, agreste, sertão pernambucano and sertão do São Francisco). In the context of health, these municipalities are administrated by 12 health management regionals (GERES). The present study had as a point of investigation the programs (PAS, PAC, Academia das Cidades or similar) and the interventions (NSFH) for promotion of physical activity developed in 152 municipalities distributed in 11 GERES. The electable municipalities had, at least, one 
ongoing program or intervention for promotion of physical activity and that was developed in the primary health care system.

The sample was recruited by convenience among adolescent users, aged between 10 and 19 years, who were being served in primary health care services, without a previous definition of a sample size to be reached. The number of participants in the present study is a result of the strategy adopted for development of the SUS+Ativo project, which predicted that every municipality visited a minimum number of interviews with users from different age groups, including when possible, those in the teenage years. A single visit was done to each municipality, in dates, times and places where the practices for PA promotion occurred.

The data collection went from February to August 2014 and July 2015, being conducted by three teams of researchers (undergraduate and graduate students in Physical Education and Adolescent Health) previously trained. The need to collect data in 2015 was due to a delay in the arrival of funding for the research project by the funding agency, which led to the interruption of the fieldwork in August 2014. The information was collected through questionnaire previously tested and validated (face validity through expert consultation) and was surveyed as a faceto-face interview. The referred instrument, available for download in www.gpesupe.org, comprehends multiple dimensions, while measures derived from four of them were used for the development of this study. In demographic dimension, the following were variables: gender (male, female); age group (10-14, 15-19 years); race (white, non-white); residency (urban, rural); educational level (incomplete primary school, incomplete elementary school, complete elementary school, complete high school or more); and, access to public garbage collection service, sewage and potable water. In the dimension of state of health, the measure of health perception was analyzed as referred to by the adolescent (good, regular, bad). In the participation dimension, the following factors were selected for analysis: time for participation in the program/intervention $(<1,1-11 ; \geq 12$ months), frequency of weekly participation in general activities (1-2, 3-4, $\geq 5$ days/week), frequency of weekly participation in physical activities (1-2, 3-4, $\geq 5$ days/week), duration of general activities ( $<30,30-59, \geq 60$ minutes), duration of physical activities ( $<30$, $30-59, \geq 60$ minutes), travel time from home to location ( $<10,10-29, \geq 30$ minutes), means of transportation used to go to location (active; passive). From the same dimension, data related to factors that motivate and difficult the participation in offered activities were extracted, besides measures of interest manifested of offered activities, by the user. Database was created through optical reading of surveys using SPHYNX® (Sphynx Software Solutions Incorporation, Washington, United States) and data were analyzed in SPSS (version 20). Due to exploratory character of the study, the data analysis used essentially procedures of descriptive statistics, such as frequency distribution (relative and absolute) and calculations of means and standard deviations.

\section{Results}

From the total existing municipalities in the 11 health regionals, 112 were visited for the development of the study. A total 991 users were surveyed, while 80 of those were adolescents (67.5\% girls), with a mean age of 15.4 years $(\mathrm{SD}=2.3)$, non-white race $(83.8 \%$ ) and resident of urban areas $(85 \%)$. Seven of the fourteen adolescents interviewd, aged between 15 and 19 years, did not conclude elementary school, representing a serours case of distortion on age/grade. As for matters of health, $77.5 \%$ of participant adolescents reported positive health perception 
("good" or "very good"). In residence infrastructure, almost the totality of participants reported living in homes with access to public garbage disposal, sewage and potable water services. On Table 1, the demographic characteristics and health perception of adolescents are represented, considering age strata.

TABLE 1 - Demographic characteristics and health perception of adolescent users of programs/interventions according to age group, Pernambuco, Brazil, 2014.

\begin{tabular}{|c|c|c|c|c|c|c|c|}
\hline \multirow{3}{*}{ Variables } & \multirow{3}{*}{ Categories } & \multicolumn{4}{|c|}{ Age group (years) } & \multirow{2}{*}{\multicolumn{2}{|c|}{ All }} \\
\hline & & \multicolumn{2}{|c|}{$10-14$} & \multicolumn{2}{|c|}{$15-19$} & & \\
\hline & & $n$ & $\%$ & $n$ & $\%$ & $n$ & $\%$ \\
\hline \multirow{2}{*}{ Gender } & Male & 21 & 65.6 & 33 & 68.8 & 54 & 67.5 \\
\hline & Female & 11 & 34.4 & 15 & 31.2 & 26 & 32.5 \\
\hline \multirow{2}{*}{ Race } & White & 7 & 21.9 & 6 & 12.5 & 13 & 16.3 \\
\hline & Non-white & 25 & 78.1 & 42 & 87.5 & 67 & 83.7 \\
\hline \multirow{2}{*}{ Residency } & Rural & 4 & 12.5 & 8 & 16.7 & 12 & 15.0 \\
\hline & Urban & 28 & 87.5 & 40 & 83.3 & 68 & 85.0 \\
\hline \multirow{4}{*}{ Educational level } & Illiterate/incomplete primary school & - & - & 1 & 2.1 & 1 & 1.3 \\
\hline & Incomplete elementary school & 12 & 37.5 & 6 & 12.5 & 18 & 22.5 \\
\hline & Complete elementary school & 19 & 59.4 & 17 & 35.4 & 36 & 45.0 \\
\hline & Incomplete high school or more & 1 & 3.1 & 24 & 50.0 & 25 & 31.2 \\
\hline \multirow{2}{*}{ Health Perception } & Negative & 7 & 21.9 & 11 & 22.9 & 18 & 22.5 \\
\hline & Positive & 25 & 78.1 & 37 & 77.1 & 62 & 77.5 \\
\hline Garbage disposal & & 30 & 93.8 & 37 & 77.1 & 67 & 83.8 \\
\hline Seweage & & 27 & 84.4 & 39 & 81.3 & 66 & 82.5 \\
\hline Potable water & & 27 & 84.4 & 39 & 81.3 & 72 & 91.1 \\
\hline
\end{tabular}

Regarding type of engagement in the program/intervention, one in every three adolescents $(36.3 \%)$ reported less than three months of participation. A similar proportion of students $(34.8 \%)$ described participating in the program/intervention for a period of three to eleven months and other $28.9 \%$ participated for, at least, 12 months. When it comes to regularity of participation in the offered activities by programs/interventions, approximately one in every two adolescents $(\sim 50 \%)$ mentioned participating in general activities and physical activities in two to three days a week. In general, $69.6 \%$ of adolescents reported spending over 60 minutes or more per session in both types of activities. After stratification by gender, a larger proportion of those participating in 60 minutes or more per session were boys when compared to girls (Figure 1-II). When questioned about the mean of transportation used to go to the location, $88.8 \%$ said they used active transport (walking or bicycling) and 56.3\% reported spending less than 10 minutes in travel from home to the location of the activities. In adolescents' evaluation, $97.5 \%$ consider the participation on activities have improved their health. Most adolescents also reported that heard about the existence of programs/interventions through friends (41.3\%), family members (16.3\%) and indication by a Physical Education teacher (16.3\%).

When questioned about the main factor that motivated/stimulated the participation in activities offered by the programs/interventions, $38.8 \%$ elected "having a better health condition", $15.0 \%$ "be more willing, enthusiastic and energetic" and other $13.8 \%$ "have a friend or family member to keep company". On the other hand, main factors that stop/difficult participation in activities are current health condition (18.8\%) and family obligations (15\%), and $18.8 \%$ did not perceive difficulties in the participation of offered activities (Figure 2). 
On the offer of programs/interventions, $92.5 \%$ of adolescents informed that offered activities were those in which they wished to participate. They were questioned on the level of interest in participating in some of the activities and it was observed that $90.0 \%$ and $87.6 \%$ of them reported elevated interest in participating respectively in sports and educational activities such as lectures and workshops (Table 2). It is important to highlight the high proportion of adolescents reporting low interest to participate in wrestling and martial arts and other practices.
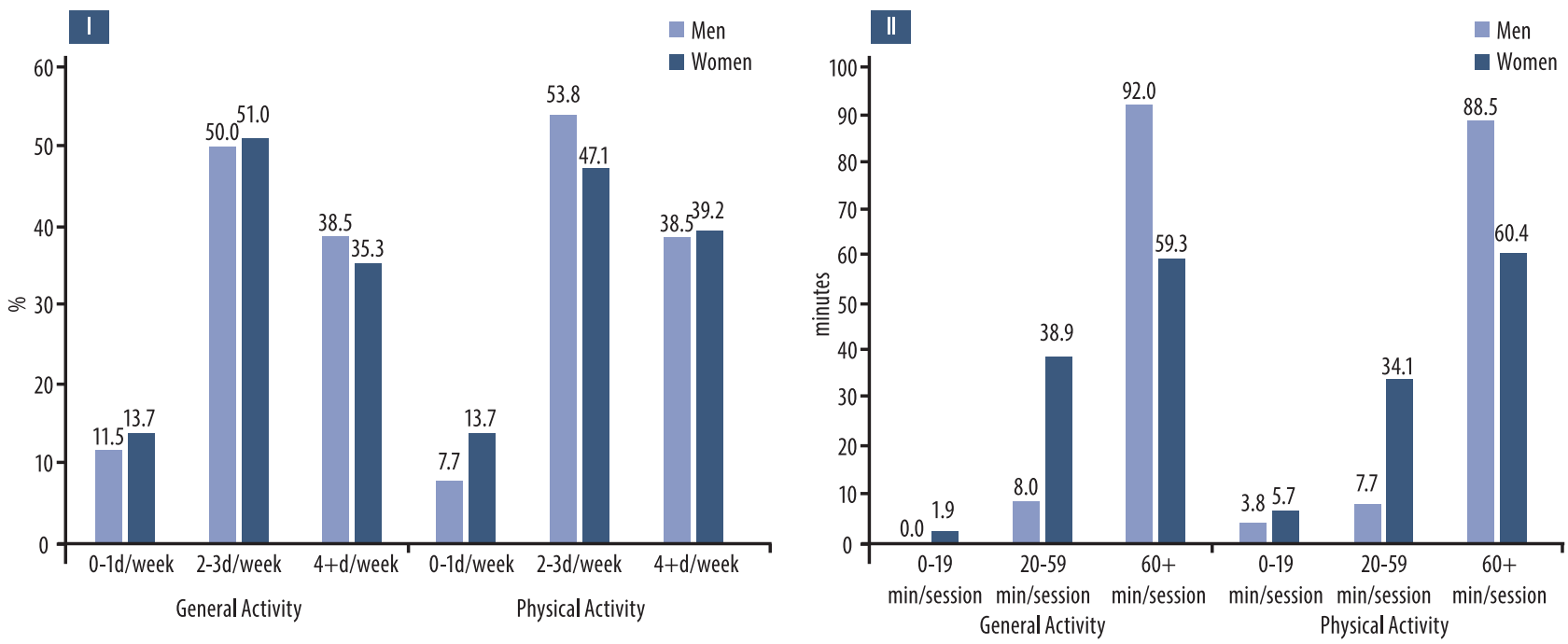

FIGURE 1 - Frequency of weekly participation (I) and duration of sessions (II) of activities in general and physical activities by gender, Pernambuco, Brazil, 2014.

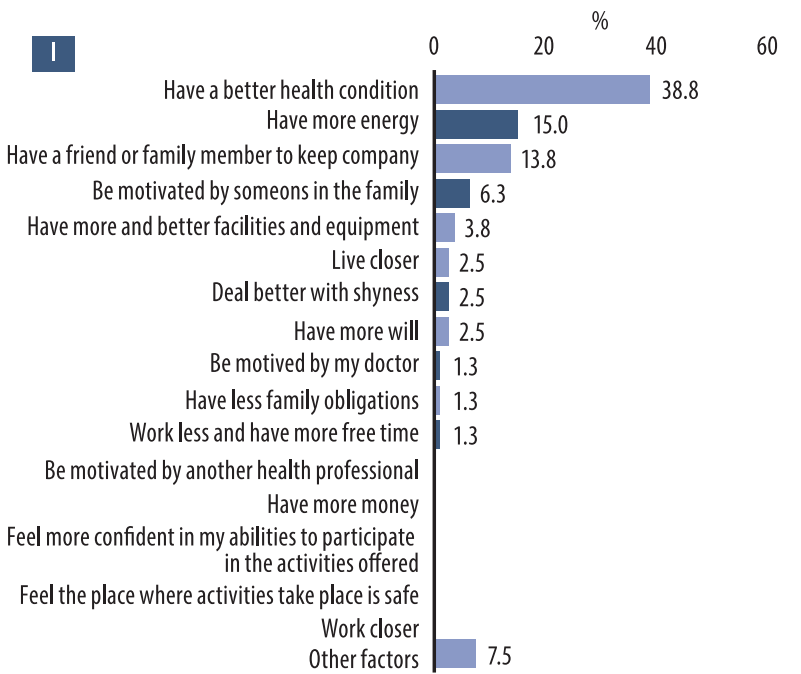

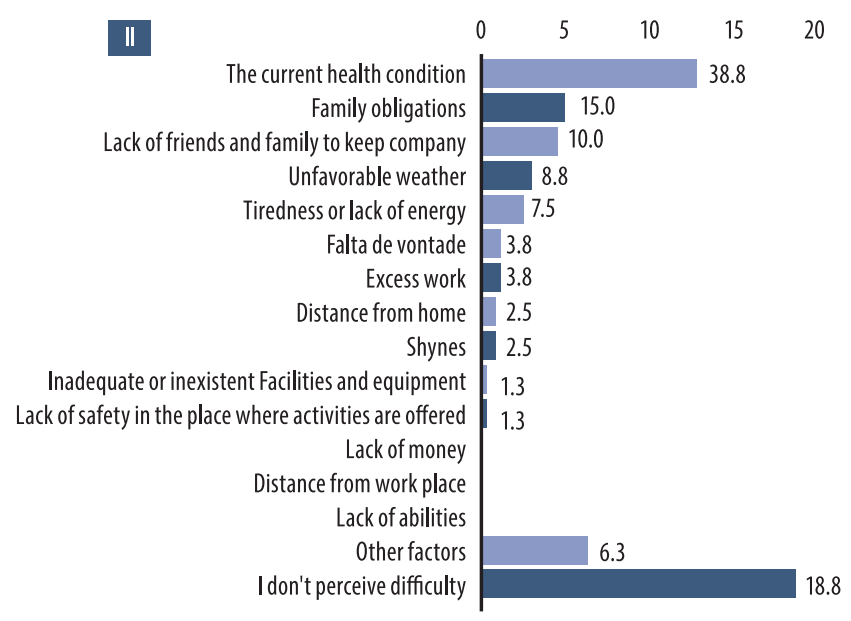

FIGURE 2 - Proportion of adolescents and factors of motivation (I) or barriers (II) to participation in activities offered by the program/intervention, Pernambuco, Brazil, 2014.

\section{Discussion}

The present study looked to describe the profile of adolescent users in interventions for physical activity promotion developed in primary health care system in the state of Pernambuco. The results showed that most adolescents were girls, aged between 15 and 19 years old, of non-white race, resident of urban areas and in homes with public garbage disposal, sewage and potable water services. The main results reported in this study were: (1) the proportion of adolescents with negative health perception was high when compared to other studies and prevalence of this health indicator in adults and older adults; (2) it was possible to 
TABLE 2 - Adolescent users' level of interest to participating in activities that may be offered in programs/interventions, Pernambuco, Brazil, 2014.

\begin{tabular}{lcccccccc}
\hline \multirow{2}{*}{ Variables } & \multicolumn{8}{c}{ Level of interested as referred by the adolescents } \\
\cline { 2 - 11 } & \multicolumn{2}{c}{ No interest } & A little interested & \multicolumn{1}{c}{ Interested } & \multicolumn{2}{c}{ Very interested } \\
\cline { 2 - 10 } & $\mathrm{n}$ & $\%$ & $\mathrm{n}$ & $\%$ & $\mathrm{n}$ & $\%$ & $\mathrm{n}$ & $\%$ \\
\hline Talks and workshops & 1 & 1.3 & 9 & 11.3 & 31 & 38.8 & 39 & 48.8 \\
\hline Aerobics classes & 6 & 7.5 & 9 & 11.3 & 27 & 33.8 & 38 & 47.5 \\
\hline Yoga and Tai chi & 25 & 31.3 & 12 & 15.0 & 26 & 32.5 & 17 & 21.3 \\
\hline Games & 2 & 2.5 & 8 & 10.0 & 26 & 32.5 & 44 & 55.0 \\
\hline Excursions and social activities & 2 & 2.5 & 8 & 10.1 & 24 & 30.4 & 25 & 57.0 \\
\hline Sports & 4 & 5.0 & 4 & 5.0 & 20 & 25.0 & 52 & 65.0 \\
\hline Wrestling and martial arts & 27 & 34.2 & 10 & 12.7 & 16 & 20.3 & 26 & 32.9 \\
\hline Swimming and water aerobics & 8 & 10.0 & 8 & 10.0 & 20 & 25.0 & 44 & 55.0 \\
\hline
\end{tabular}

identify that approximately one in every five adolescents, current health condition was pointed out as the main factor that could prevent participation in the offered activities; (3) even though approximately one in every four adolescents refer to a negative health perception, the scenario observed reveals a good participation (weekly frequency and duration of sessions) of these users in the offered activities by the programs/interventions.

The practice of physical activities in this phase of life provides many benefits to health, beyond decreasing the chance of these youngsters becoming sedentary adults $^{12,13}$. Offering opportunities for physical activity practice may be an effective strategy for promotion, but the clientele of community programs is constituted by middle aged and older adults ${ }^{10,11}$. Furthermore, the results of the studies have shown the precariousness of attention to adolescent population in quantity of health services directed to the adolescent population ${ }^{11,14,15}$.

Results focusing on physical activity promotion in the school context show that interventions of this type are effective for change in health and increased levels of physical activities ${ }^{16}$. However, in order to reach out to adolescents, the activities developed in primary health care need to be planned taking into consideration the needs and specific interests of this population subgroup, a challenge in a scenario where usually information is ignored by managers and professionals involved.

The results of this study suggest there is a higher participation of adolescents who are female in the programs/interventions offered in primary health care. Even though boys present high levels of physical activity than girls ${ }^{17}$, the access of those to health services offered in primary health care is usually higher ${ }^{18}$. One of the possible explanations for these findings, beyond cultural apology, may be in the type of activities offered as part of the interventions, usually more adequate to the female interest ${ }^{4}$.

Most programs/interventions for physical activity promotion investigated in this study run during weekdays (Monday through Friday) on morning and afternoon shifts. The frequency of activities is very similar to those offered in national programs for physical activity $(\mathrm{RNAF})^{11}$ and the CuritibAtiva program ${ }^{19}$. In general, the frequency ( 5 days/week) and duration of sessions for physical activity practice are adequate as strategies for users to reach recommendations for physical activity practice $^{20}$. However, one in every two adolescents reported participating in only two or three days a week in physical activities, which shows the capacity of programs/interventions are not being fully used. A study in the city of Recife allowed the identification of the population using the Academia da Cidade Program who 
were participating in activities four or more times a week, for over 60 minutes ${ }^{4}$.

Regular physical activity practice is determined by individual, social and environmental factors. In this study, the main reasons for participation in activities offered by programs/interventions are related to health (improve health, get in shape and prevent disease). Among the main barriers identified, besides the currenthealth condition, social factors (family obligations and lack of friends or family to keep company) were also among the main reasons. Moreover, positive experiences in Physical Education classes also have been associated to physical activity practice outside of school context ${ }^{21}$. The perception of barriers of personal order, laziness and lack of willingness were identified as factors associated to lack of involvement with physical activity practices in a study with adolescents ${ }^{22}$. Other factors identified in this age group were: lack of company, occupation/work hours, lack of time, lack of adequate places and lack of safety in the environment ${ }^{22-24}$.

A few limitations of this study must be presented, in special the impossibility to have a probabilistic sample of adolescent users of programs/interventions, aspect that demands attention when generalizing the findings. The use of a questionnaire can conduct to bias of information and some adolescents may have omitted information by forgetfulness or the intrusion provoked by the interviewer. This is an exploratory study; therefore, it is recommended caution when reading the interpretations and application of these findings.

On the other hand, even with exploratory characteristics, this study has positive points, in special, the survey conducted with adolescents from diverse cities in Pernambuco. The results of the present study allow to conclude that adolescent users who were interviewed are heterogeneous in demographic characteristics, like to participate in the activities that are being offered and believe they may have health benefits derived from this participation. The health condition (current and desired) represents both a barrier as well as motive for participation in the activities; aspect that must be well explored in future studies.

\section{Acknowledgements/ funding}

We thank all those people who directly or indirectly contributed to this project, especially users, professionals and managers, researchers, GPES e funding sources (CNPQ, FACEPE and CAPES).

\section{Collaborators}

All the authors contributed in the creation of the project or analysis and interpretation of the data, writing the manuscript or critically reviewing for all intellectual content, as well as the approval of the final version to be published.

\section{References}

1. Brasil. Ministério da Saúde. National Policy for Health Promotion/Ministry of Health, Secretary of Health Vigilance, Secretary of Health Care. - 3. ed. - Brasília: Ministério da Saúde, 2010.

2. Ferreira MS, Najar AL. Programs and campaigns for promotion of physical activity. Ciênc Saúde Coletiva. 2005; 10 (Suppl): 207-19.

3. Brasil. Ministério da Saúde. Academia da Saude Program in the SUS. Portaria n. 719, de 7 de abril de 2011. Brasília: Ministério da Saúde, 2011.

4. Hallal PC, Tenório MCM, Tassitano RM, Reis RS, Carvalho YM, Cruz DKA, et al. Evaluation of the program for promotion of physical activity Academia da Cidade in Recife, Pernambuco, Brazil: perceptions of users and non-users. Rev Saúde Públ. 2010; 26(1): 70-8. 
5. Brasil. Ministry of Heath. Nucleus for Support to Family Health. Portaria 154/2009. Brasília: Ministério da Saúde, 2009.

6. Mendonça BCA, Toscano JJO, Oliveira ACC. From diagnosis to action: experiences in the Academia da cidade program in city of Aracaju: promoting health through physical activity. Rev Bras Ativ Fis Saúde. 2009; 14(3): 211-6.

7. Hallal PC, Andersen LB, Bull FC, Guthold R, Haskell W, Ekelund U. Global physical activity levels: surveillance progress, pitfalls, and prospects. Lancet. 2012; 380:247-57.

8. Barufaldi LA, Abreu GA, Coutinho ESF, Bloch KV. Meta-analysis of the prevalence of physical inactivity among Brazilian adolescents. Rev Saúde Públ. 2012;28:1019-32.

9. Tenório MCM, Barros MVG, Tassitano RM, Bezerra J, Tenório JM, Hallal PC. Physical activity and sedentary behavior in high school adolescents. Rev Bras Epidemiol. 2010;13(1):100-7.

10. Amorim TC, Knuth AG, Cruz DKA, Malta DC, Reis RS, Hallal PC. Description of municipal programs for physical activity promotion funded by the Ministry of Health. Rev Bras Ativ Fis Saúde. 2013; 18(1): 63-74.

11. Knuth AG, Malta DC, Cruz DC, Freitas PC, Lopes MP, Fagundes J, et al. National Physical Activity Network from the Ministry of Health: evaluation results and strategies. Rev Bras Ativ Fis Saúde. 2010; 15 (4): 229-33.

12. Silva PVC, Costa Jr AL. Effects of physical activity to the health of children and adolescents. Psicol Argum. 2011; 29 (64): 41-50.

13. Fonseca VM, Sichieri R, Veiga GV. Associated factors to obesity in adolescents. Rev Saúde Públ. 1998; 32: 541-9.

14. Ferrari RAP, Thomson Z, Melchior R. Attention to adolescent health: perception of doctors and nurses in teams of family health. Rev Saúde Públ. 2006; 22 (11):2491-5.

15. Vieira RP, Machado MFAS, Bezerra IMP, Machado CA. Participation of adolescents in the Family Health Strategy from the Theory-methodology structure of an habilitation participation. Rev Latinoam Enfermagem. 2014; 22(2): 309-16.

16. World Health Organization. What is the evidence on school health promotion in improving health or preventing disease and, specifically, what is the effectiveness of the health promoting schools approach? Copenhagen: World Health Organization; 2006.

17. Ferreira JO, Jardim PCBV, Peixoto MRG. Evaluation of project for promotion of health in adolescents. Rev Saúde Públ. 2013; 47(2): 257-65.

18. Simões EJ, Hallal P, Pratt M, Ramos L, Munk M, Damascena W, et al. Effects of a Community Based, Professionally Supervised Intervention on Physical Activity Levels Among Residents of Recife, Brazil. Am J Public Health. 2009; 99(1):68-75.

19. Hallal PC, Reis RS, Hino AAF, Santos MS, Grande D, Krempel MC et al. Evaluation of community physical activity promotion programs: the case of Curitiba, Parana. Rev Bras Ativ Fis Saúde. 2009; 14 (2): 104-14.

20.20. World Health Organization. Global recommendations on physical activity for health. Geneva: World Health Organization; 2010.

21. Bryan CL, Solmon MA. Student Motivation in Physical Education and Engagement in Physical Activity. J Sport Behav. 2012; 35(3):267-85.

22. Santos MS, Fermino RC, Reis RS, Cassou AC, Añez CRR. Barriers for physical activity practice in adolescents. A focus groups study. Rev Bras Cineantropom Desempenho Hum. 2010; 12 (3): 137-43.

23. Drambos DD, Lopes LFD, Santos DL. Perceived barriers and physical activity barriers of adolescents in a Southern Brazilian city. Rev Bras Cineantropom Desempenho Hum.2011; 13(6): 422-8.

24. Muller WA, Silva MC. Barriers to physical activity practice in adolescents from rural areas of Rio Grande do Sul. Rev Bras Ativ Fis Saúde. 2013; 18(3): 344-6.

CORRESPONDING

AUTHOR

CAROLINE RAMOS DE MOURA SILVA

carolinerms@gmail.com
Rua Castro Alves, no 437, Encruzilhada,

Recife-PE.

Postal code: $52030-060$

Telephone: (81) 3241-9546.
RECEIVED 02/12/2015

APPROVED $\quad 17 / 03 / 2016$ 